\title{
Mengiplementasikan Tugas Sosial Gereja dalam Kemajemukan pada Masa Pandemi Covid-19
}

\author{
Evans Dusep Dongoran \\ Sekolah Tinggi Teologi REAL, Batam \\ evansdongoran@gmail.com
}

\begin{abstract}
Pluralism is a reality that cannot be ignored by the Indonesian people. Pluralism requires everyone to be able to open up and think positively to create a pluralist sense of togetherness and have an attitude of helping each other, especially in the current Covid-19 pandemic situation that has hit the world, including Indonesia. The church is called to be able to carry out social tasks during a crowded society during this Covid-19 pandemic. The purpose of this paper is to implement the Church's social work in pluralism during the Covid-19 pandemic. This writing uses qualitative methods in data and text analysis, namely paying attention to the symptoms that arise as a result of the covid-19 pandemic; poverty and deprivation so that the Church is involved in social problems to take part in helping and assisting others regardless of ethnic and religious differences by explaining the theological basis in building a pluralist togetherness from the foremost law, the example of Jesus' life and God's love for all human beings.
\end{abstract}

Keywords: church; Covid-19; pluralism; pluralist togetherness

\begin{abstract}
Abstrak
Kemajemukan merupakan kenyataan yang tidak dapat diabaikan bangsa Indonesia. Kemajemukan menuntut setiap orang untuk dapat membuka diri dan berpikiran positif agar terciptanya rasa kebersamaan yang pluralis serta memiliki sikap saling tolong menolong, terlebih dalam situasi pandemi Covid-19 saat ini yang melanda dunia termasuk Indonesia. Gereja terpanggil untuk dapat melakukan tugas sosial ditengah masyarakat yang mejemuk pada masa pendemik Covid-19 ini. Tujuan penulisan ini adalah untuk mengimplementasikan tugas sosial gereja dalam kemajemukkan pada masa pandemi Covid-19. Penulisan ini menggunakan metode kualitatif dalam analisis data dan teks yakni memperhatikan gejala yang timbul akibat dari pandemi Covid-19; kemiskinan dan kekurangan agar Gereja terlibat permasalahan sosial untuk ambil bagian dalam menolong dan membantu orang lain tanpa melihat perbedaan suku dan agama dengan memaparkan dasar teologis dalam membangun kebersamaan yang pluralis dari hukum yang terutama, teladan hidup Yesus dan kasih Allah terhadap semua manusia.
\end{abstract}

Kata kunci: Covid-19; gereja; kemajemukan; kebersamaan pluralis

\section{PENDAHULUAN}

Indonesia adalah negara multikultural. Kemajemukan masyarakat Indonesia dianggap sebagai kekayaan atau keistimewaan bagi bangsa Indonesia. Kemajemukan, khususnya pluralitas agama, bahkan sudah menjadi sesuatu ciri khas yang diketahui dan disepakati bersama di Indonesia. Kekayaaan keberagaman yang ini dapat dijadikan modal bersama untuk membangun Indonesia. Semua elemen bangsa dapat bersatu sebagai kekayaan 
sosial yang berharga untuk berperan membangun negara, di mana dalam penerimaan itu orang bersedia untuk hidup, bergaul, dan kerjasama membangun negara. ${ }^{1}$

Gereja merupakan bagian dari kemajemukan dalam masyarakat, sehingga gereja harus dapat memainkan perannya ditengah masyarakat, memberikan dampak bagi lingkungan sekitarnya, dan menyadari panggilan imannya untuk mewujudkan kesejahteraan dalam konteks kemajemukan. ${ }^{2}$ Namun sering terjadi gereja kurang melaksanakan tugas sosialnya, dikarenakan gereja kurang peduli terhadap masalah-masalah sosial yang terjadi di sekitarnya, seperti kemiskinan dan penderitaan. ${ }^{3}$ Yakub B. Susabda mengritisi posisi gereja dengan menyatakan kehadiran gereja di bumi pertiwi ini sebagai kehadiran tanpa peran yang berarti, "Selama ini peran yang dimainkan adalah peran yang terlalu kecil untuk anugerah dan kesempatan yang besar. Gereja semakin kebingungan peran, krisis identitas, karena kita meninggalkan jati diri kita sebagai orang yang ditebus." 4 Gereja selalu berfokus pada kegiatan religius yang hanya mengembangkan spiritualitas, tetapi mengabaikan kehidupan sosial.

Pandemi Covid-19 adalah suatu fenomena yang saat ini sedang menggemparkan Indonesia maupun dunia. Penyebaran Covid-19 ini sungguh sangat cepat, pada tanggal 12 Maret 2020, WHO mengumumkan Covid-19 sebagai pandemi. ${ }^{5}$ Keadaan ini sungguh sangat berdampak terhadap kehidupan sosial dan kesejahteraan masyarakat Indonesia. Pemerintah Indonesia mencoba menerapkan berbagai kebijakan, seperti social distancing, stay at home, hingga Pemberlakuan Pembatasan Kegiatan Masyarakat (PPKM) guna memutus mata rantai penyeberan virus ini, akan tetapi kebijakan ini justru berdampak kepada kehidupan social masyarakat. Ruang gerak kehidupan sosial di dalam masyarakat semakin berkurang bahkan tertutup dengan lingkungan sekitar. Keadaan ini menambah kesenjangan sosial dalam masyarakat, meningkatkan sikap induvidualisme, kecurigaan satu dengan yang lain dan kurangnya rasa persaudaraan.

Penyebaran Covid-19 tidak hanya soal banyaknya orang yang terpapar, melainkan dampaknya juga terhadap kehidupan ekonomi masyarakat, yaitu pengangguran dan kemiskinan. ${ }^{6}$ Investasi, perdagangan, usaha mikro, kecil dan menengah (UMKM) dan pariwisata, nilai tukar rupiah semakin anjlok dan meningkatnya pengangguran menambah penderitaan masyarakat. ${ }^{7}$ Gejala yang terjadi di masyarakat timbul kelaparan akibat tidak adanya makanan bahkan ada yang sampai meninggal dunia. ${ }^{8}$

\footnotetext{
${ }^{1}$ Rosalina Ginting and Kiki Ayaningrum, “Toleransi Dalam Masyarakat Plural,” Jurnal Majalah Ilmiah Lontar (2009).

${ }^{2}$ Dorkas Orienti Daeli and Sonny Eli Zaluchu, “Analisis Fenomenologi Deskriptif Terhadap Panggilan Iman Kristen Untuk Kerukunan Antar Umat Beragama Di Indonesia," SUNDERMANN: Jurnal Ilmiah Teologi, Pendidikan, Sains, Humaniora dan Kebudayaan 1, no. 1 (2019): 44-50.

${ }^{3}$ Ricardo F Nanuru and Lomas Beatris Limpong, "Lomas Beatris Limpong 2," Jurnal UNIERA 3, no. 1 (2014): 51-60.

${ }^{4}$ Hendra G. Mulia (Editor), Perjuangan Menantang Zaman: Kumpulan Esai Sebagai Penghargaan Kepada Pendeta Stephen Tong pada HUT ke-60 (Jakarta:Reformed Institut Press, 2000), 27

${ }^{5}$ World Health Organization,https://www.who.int/dg/speeches/detail/who-director-generals-opening-remarks-at-the-media-briefing-on-covid-19---11-march-2020

${ }^{6}$ Chairul Baharudin, Iksan and Muhammad Abdi, Nur, "Ancaman Krisis Ekonomi Global Dari Dampak Penyebaran Virus Corona (Covid-19)," AkMen Jurnal Ilmiah 17, no. 1 (2020): 710-718.

${ }^{7}$ Silpa Hanoatubun, "Dampak Covid-19 Terhadap Perekonomian Indonesia," Journal of Education, Psychology and Counseling 2, no. April (2020): 146-153.

${ }^{8} \mathrm{https} / / /$ health.grid.id/read/352115758/psbb-sudah-berjalan-warga-serang-meninggal-kelaparansetelah-2-hari-tak-makan-covid-19?page=all
} 
Gereja harus hadir di tengah-tengah permasalahan yang ada di masyarakat. Gereja terpanggil untuk dapat melakukan tugas sosialnya ${ }^{9}$ di tengah kemajemukan pada masa pandemi Covid-19 ini. ${ }^{10}$ Tugas panggilan gereja harus bersifat holistik sebagaimana pelayan yang Yesus lakukan, menunjukkan pelayanan yang utuh dan menyeluruh dari seluruh aspek kehidupan dan kebutuhan manusia. Menciptakan kondisi sosial yang kondusif di tengah kekuatiran dan keretakan dalam masyarakat, serta melakukan tindakan sosial bagi masyarakat yang terdampak Covid- 19. Artikel ini bertujuan untuk menunjukkan tugas gereja yang tidak boleh diabaikan dalam kerangka kehidupan sosial.

\section{METODE}

Tulisan ini termasuk penelitian kualitatif, yaitu penelitian yang berfokus pada hubungan-hubungan sosial di mana teori dikembangkan dari hasil-hasil penelitian empiris. ${ }^{11}$ Pendekatan yang digunakan adalah tinjauan literatur mengenai topik mengimplementasikan tugas sosial gereja dalam kemajemukan dan penelitian-penelitian terkait yang telah ada sebelumnya, baik dalam bentuk buku, artikel, maupun dokumendokumen lain. Dalam hal ini, penulis menyelidiki peran gereja dalam tugas sosial dimasa pandemi Covid-19 dengan membaca dan menganalisis sejumlah konsep, teori, dan gagasan yang telah dipublikasikan sebelumnya.

\section{HASIL DAN PEMBAHASAN}

\section{Tugas Sosial Gereja}

Gereja adalah suatu lembaga yang konkret dan kelihatan, namun tidak sama dengan lembaga-lembaga di dunia karena merupakan persekutuan orang percaya. Dari sudut pandang Alkitab setiap orang Kristen adalah bait Allah, Roh Allah diam di dalamnya (1Kor. 3:16:2 ; 2Kor. 6:16). Oleh karena itu, ketika berbicara tentang gereja fokus perhatian bukan saja pada gedung gerejanya, melainkan juga pada orang Kristen secara individu dan persekutuan orang-orang percaya sebagai suatu persekutuan di tengahtengah masyarakat dan dunia.

Gereja sebagai lembaga ilahi yang berada dalam kemajemukan memiliki tugas penting yang mencakup tiga aspek, yakni: marturia, atau bersaksi (Mat. 6:28, 18-20); koinonia, atau persekutuan antara jemaat dengan Kristus, dan jemaat dengan jemaat (1Pet 1:9-10); diakonia, atau melakukan pelayanan kasih bagi kesejahteraan segenap umat manusia (Mat. 4:23). Dalam lima dokumen keesaan gereja, tugas panggilan gereja ini memiliki unsur keesaaan, kesaksian, dan pelayanan. ${ }^{12}$ Sebagai wujud persekutuan orang yang beriman kepada Tuhan Yesus, gereja mempunyai dua dimensi yang tidak dapat dipisah-pisahkan dalam keberadaannya dan kehidupannya, yaitu dimensi spiritual

\footnotetext{
${ }^{9}$ Yushak Soesilo, "Pentakostalisme Dan Aksi Sosial: Analisis Struktural Kisah Para Rasul 2 : 4147,” DUNAMIS: Jurnal Teologi dan Pendidikan Kristiani 2, no. 2 (2018): 136-151, http://sttintheos.ac.id/e-journal/index.php/dunamis/article/view/172/134.

${ }^{10}$ Johannis Siahaya and Harls Evan R Siahaan, "Menggagas Hospitalitas Pentakostal: Membaca Ulang Kisah Para Rasul 2: 44-47 Di Masa Pandemi," DUNAMIS: Jurnal Teologi dan Pendidikan Kristiani 5, no. 2 (2021): 426-439.

${ }^{11}$ Sonny Eli Zaluchu, "Strategi Penelitian Kualitatif Dan Kuantitatif Di Dalam Penelitian Agama," Evangelikal 4, no. 1 (2020): 28-38.

${ }^{12}$ PGI, Lima Dokumen Keesaan Gereja,(Jakarta :BPK Gunung Mulia,1996), hal 9
} 
dan dimensi sosial. Dimensi spiritual berbicara tentang hubungan manusia dengan Allah sedangkan dimensi Sosial hubungan antara sesama manusia.

Dalam konteks Indonesia saat ini, persoalan sosial sudah tidak asing lagi dalam kehidupan masyarakat. Segala hal sedang terjadi dan tidak butuh peta untuk melihatnya karena sedang terjadi saat ini seperti kemiskinan, dianiaya, pemaksaan kehendak, kejahatan, pelecehan dan sebagainya. Oleh karena itu peran sosial Gereja sangat dibutuhkan dan relevan. Sosial Gereja mengupayakan kesejahteraan seluruh masyarakat. ${ }^{13}$ Manusia adalah makhluk yang diciptakan Tuhan tidak untuk hidup sendiri. Oleh karena itu manusia adalah makhluk sosial, yang membutuhkan satu dengan yang lain, oleh karena itu bisa saling melengkapi. Sebagai makhluk sosial, akan mengalami banyak persoalan dan juga kebutuhan dalam hidup ini. Jika persoalan dan kebutuhan tidak teratasi dan tidak ada jalan keluarnya, maka tentunya akan muncul persoalan sosial seperti yang dikutip oleh Arlianus Larosa yaitu: "kemiskinan, keterlantaran, pelecehan, manipulasi hukum, dan bahkan kriminalitas. Oleh karena itulah maka manusia membutuhkan pelayanan sosial. ${ }^{14}$

Sosial gereja adalah salah satu hasil dari cinta kasih Allah yang dinyatakan oleh Kristus Sang Penebus dosa manusia yang terhimpun dalam Roh Kudus. Tentunya gereja haruslah memiliki tujuan untuk penyelamatan. Adapun Gereja telah hadir dalam dunia ini, terhitung juga dari orang-orang yang ada dalam dunia ini. Orang-orang dalam dunia ini adalah keluarga, dan keluarga dalam Kristus dengan dilengkapi sarana-sarana yang tepat untuk mewujudkan persatuan yang nyata dan bersifat sosial. ${ }^{15}$ Demikianlah harusnya gereja hadir dalam dunia yang bersifat sosial supaya menempuh perjalanan bersama dengan seluruh umat manusia sehingga bersama dengan seluruh umat manusia, dan juga sosial gereja bisa mejadi ragi dan dampak bagi masyarakat.

Adapun sosial gereja juga haruslah menyalurkan cahaya Allah kepada seluruh masyarakat dan memberikan makna yang berarti, seperti menyembuhkan yang terluka, mendidik yang bodoh, mengangkat martabat pribadi manusia melalui kegiatan sosial gereja. Begitulah semestinya gereja bersama anggota-anggotanya melakukan hal yang banyak untuk lebih memanusiawikan keluarga manusia beserta sejarahnya. Selain itu, gereja menunjukkan kepada dunia bahwa adanya satu kesatuan dari sosial yang lahiriah dan yang murni adalah bersumber pada satu kesatuan hati. Gereja mampu berbaur bersama-sama masyarakat pada masa sekarang dengan rasa mengasihi secara efektif. ${ }^{16}$

Secara sosiologis gereja tidak bisa dipisahkan dari masyarakat. Karena umat gereja juga adalah bagian dari masyarakat. Dan gereja adalah ruang publik yang bisa beraktivitas menyuarakan, dan juga bisa memperjuangkan kepentingan masyarakat. Oleh karena itu, umat gereja juga mengambil bagian dalam kemajuan masyarakat, terutama kepada yang terpinggirkan, terabaikan, dan miskin. Disinilah peran sosial gereja, sebagai jembatan untuk kepentingan masyarakat, sehingga umat gereja terlibat dalam berbagai kegiatan. Ruang publik merupakan adalah sebuah fenomena sosial yang didasari

${ }^{13}$ S. Th Pdt. Arliyanus Larosa, Misi Sosial Gereja (Jakarta: Yayasan Kalam Kudus, 2001). Hal. 8

${ }^{14}$ Yuli Yanti, "Misi Pelayanan Sosial Di Masa Pandemi Bagi Pembinaan Warga Gereja Jemaat Baru," https://osf.io/sq9h5 (n.d.).

15 DOKPEN KWI, Ajaran Sosial Gereja Tahun 1891-1991 (Bogor: Grafika Mardi Yuana, 2011). Hal. 319

16 Ibid. Hal 321 
oleh tindakan dan hubungan. ${ }^{17}$ Gereja harus memperhatikan juga akan hal-hal yang ada di tengah-tengah mayasrakat, seperti kebudayaan dan juga kesejahteraan, karena dalam dunia ini banyak tempat yang diabaikan. Itu sebabnya, perlunya sosial gereja sehari-hari melihat dan melakukan kegiatan yang rutin untuk bisa lebih memahami kebudayaan setempat dan kesejahteraan yang diperlukan sesuai dengan perubahan zaman. Dengan mengajarkan tujuan keselamatan itu, gereja tidak hanya menyampaikan kepada manusia hidup ilahi, melainkan dengan cara tertentu memantulkan terangnya kepada seluruh dunia, terutama dengan penyembuhan dan mengangkat martabat manusia, dengan meneguhkan susunan masyarakat dan dengan memberi arti maksud yang lebih mendalam pada karya manusia sehari-hari. ${ }^{18}$

\section{Dasar Teologis Tugas Sosial Gereja dalam Kemejemukan}

Bebarapa dasar dan prinsip umat Tuhan secara teologis hidup di tengah pluralitas agama

\section{Mengasihi Allah dan Mengasihi Sesama Manusia.}

Dasar tugas Gereja ditengah kemajemukan harus dapat seimbang antara mengasihi Allah dan mengasihi manusia. Mengasihi Allah dan mengasihi manusia adalah suatu perintah Tuhan yang harus sama-sama dilakukan oleh umat Tuhan. Kita tidak dapat mengasihi Allah tanpa mengasihi sesama manusia. Ketika seorang ahli Taurat menanyakan kepada Yesus tentang hukum manakah yang terutama dalam hukum taurat? Yesus menjawab "Kasihilah Tuhan Allahmu...Itulah hukum yang terutama dan yang pertama. Dan hukum yang kedua...ialah kasihilah sesamamu manusia seperti dirimu sendiri” (Mat. 22:37-39). Kasih terhadap Tuhan Allah adalah yang pertama dan terutama, sesuatu yang mutlak dan totalitas dari umat Tuhan. Kasih kepada Allah itu satusatunya dasar kehidupan kita, kasih kepada sesama harus didasari kasih kepada Allah. Kasih terdahap Allah harus tercermin dalam kasih kita kepada sesama (1Yoh. 4:20). Kasih kepada Allah adalah yang terutama dan pertama, kasih kepada sesama berdasarkan kepada yang utama itu. ${ }^{19}$

Kasih kepada Allah tidaklah sempurna jika tidak disertai dengan kasih terhadap sesama. Kasih terhadap sesama tanpa didasari kasih kepada Allah maka kasih hanyalah kebohongan dan semu. Malcolm Brownlee menjelaskan ada tiga sebab ketidakmungkinan kasih kepada Allah kalau kita tidak mengasihi sesama kita, Pertama, mengasihi saudara kita yang kelihatan lebih mudah daripada mengasihi Allah yang tidak kelihatan. Kasih kepada Allah perlu diwujudkan dalam pertolongan yang konkret kepada sesama, karena jika hal itu tidak dinyatakan, maka hal itu adalah kosong dan munafik. Kedua, kita tidak bisa mengasihi Allah Bapa tanpa mengasihi anak-anak-Nya. Ketiga, kalau kita menutup hati kepada sesama, maka kita juga akan menutup hati kepada Allah. Seorang yang menutup hatinya kepada kebutuhan sesamanya pasti menutup diri kepada kasih yang hendak diberikan kepadanya kepada Allah. ${ }^{20}$

\footnotetext{
${ }^{17}$ Ricardo Freedom Nanuru, Gereja Sosial (Yogyakarta: CV Budi Utama, 2020). Hal. 70.

${ }^{18}$ B. Kieser SJ, Solidaritas 100 Tahun Ajaran Sosial Gereja (Yogyakarta: Penerbit Kanisius, 1992). $87-88$

${ }^{19}$ Malcolm Brownlee, Tugas Manusia Dalam Dunia Milik Tuhan, (Jakarta: BPK Gunung Mulia, 2004), 24

${ }^{20}$ Ibid.
} 
Dasar mengasihi sesama karena Allah juga mengasihi semua manusia. Mazmur 145:9 bmengatakan "Tuhan ibu baik kepada semua orang dan penuh rahmat terhadap segala yang dijadikannya." Kata "semua" yang dimaksud di sini adalah semua umat manusia ciptaannya, termasuk orang yang berbeda iman. Allah menciptakan matahari yang sama dan bumi dan bulan yang sama juga untuk dinikmati semua manusia. Sebagaimana Allah yang kita kasihi juga mengasihi semua manusia, hendaknya kita sebagai umat Tuhan juga harus mengasihi sesama manusia.

\section{Teladap Hidup Yesus}

Yesus Kristus selama berada di dunia kehidupannya memberikan teladan bagi umat Tuhan untuk hidup dalam pluralitas, Yesus hidup ditengah-tengah pluralitas agama dan kepercayan yang ada pada saat itu. Sebagai seorang Yahudi ia harus tetap mempertahankan kemurnian Yudaisme ditengah-tengah pengaruh Helenisme dan agama Romawi. Cara kehidupan Yesus tentu berlawanan dengan kelompok-kelompok yang hidup pada waktu itu. Brownlee membandingkannya dengan orang-orang Zelot dan Essene. Kaum Zelot ingin mendirikan Kerajaan Allah di dunia dengan cara revolusioner. Kaum Essene menjauhkan diri dari dunia untuk bertapa dan hidup murni sampai mesias datang. ${ }^{21}$

Sekalipun Yesus hidup di tengah pluralitas agama tidak pernah berkompromi terhadap keadaan yang ada. Meskipun para Imam pada waktu itu banyak yang menyimpang dan terpengaruh dengan Helenisme dan agama Romawi, seperti korban dipersembahkan setiap hari di bait Allah kepada Yahwe atas nama kaisar Roma. ${ }^{22}$ Bait Allah dinodai oleh korban babi yang bagi orang Yahudi merupakan kenajisan. ${ }^{23}$ Ia tidak sanggup berkompromi dengan ketidakadilan. Ia menentang orang-orang yang menyalahgunakan kedudukannya atau tidak peduli kepada penderitaan orang sengsara. Namun dalam melakukannya Ia tidak melakukannya dengan kekerasan dan gerakan revolusioner perang. Yesus melakukan pembaharuan secara lengkap. Pembaharuan itu berarti bahwa struktur-struktur masyarakat dan hati manusia diperbaharuhi. Yesus tidak memperhatikan individu saja atau masyarakat saja. Ia memperhatikan individu dan masyarakat. ${ }^{24}$ Yesus dalam menggarami dan menerangi dunia tidak dengan kompromi ataupun dengan kekerasan, namun Ia menggarami dan menerangi melalui cara hidupnya yang penuh dengan kasih.

Kehidupan Yesus tidak pernah terlepas dari kehidupan sosial. Yesus tidak pernah menganjurkan umatnya menghindari atau menarik diri dari kehidupan sosial. ${ }^{25}$ Yesus sangat peduli dengan kehidupan sosial. Ia datang menyampaikan kabar baik kepada orang miskin, orang yang tertindas dan orang yang lemah (Luk. 4:18-19). Umat Tuhan tidak boleh melihat kehidupan dunia sebagai sesuatu yang harus diterima ataupun dijauhkan. Karena dunia penuh dengan dosa. Karena itu dunia perlu diperbaiki. Umat Tuhan dipanggil oleh Allah untuk hidup dalam lingkungan masyarakat yang pluralis dan peduli dengan keadaan masyarakat yang ada, sambil berusaha menjadikan masyarakat lebih sesuai dengan kehendak Allah melalui kesaksian hidup kita.

\footnotetext{
2004), 13

${ }^{21}$ Malcolm Brownlee, Tugas Manusia Dalam Dunia Milik Tuhan (Jakarta: BPK Gunung Mulia,

${ }^{22}$ Donald B. Kraybill, Kerajaan Yang Sungsang (Jakarta: BPK Gunung Mulia, 2012), 40

${ }^{23}$ Ibid., 25

${ }^{24}$ Ibid., 15

${ }^{25}$ Ibid., 3
} 


\section{Tuhan Mengasihi Semua Suku Bangsa}

Kitab Mazmur 145:9 mengatakan "Tuhan itu baik kepada semua orang dan penuh rahmat terhadap segala yang dijadikannya." Tuhan Allah mengasihi semua ciptaanya Ia memberikan Matahari untuk semua orang, untuk yang jahat maupun yang baik dan memberikan hujan untuk semua manusia, agar segala suku bangsa dapat menikmati kebaikan Tuhan. Dalam kisah Para Rasul menceritakan bagaiman Injil dapat disampaikan bagi seluruh bangsa. Diawali oleh perjumpaan Petrus dengan Kornelius seorang prajurit Roma (Kis. 10), di mana Petrus pada saat itu memiliki sikap eksklusivisme agama Yahudi yang sangat keras dan tertutup. Namun dalam perjumpaannya dengan Kornelius, Petrus baru mengerti bahwa Allah tidak membedakan orang (Kis. 10:34). Oleh karena itu, perbedaan suku bangsa dan agama jangan menjadi hambatan bagi setiap orang untuk dapat berbuat baik, sebab mereka juga diterima oleh Tuhan.

\section{Membangun Kebersamaan yang Pluralis}

Di tengah pandemi Covid-19 perlu membangun kebersamaan yang pluralis. Kata Pluralitas adalah suatu pengakuan akan keberagaman agama dan berusaha memahami perbedaan yang ada. Pluralitas yang berpondasikan solidaritas individual yang mendorong setiap agama untuk berkontribusi, saling take and give dan menghargai perbedaan itu. ${ }^{26}$ Pluralis yang dimaksud dalam tulis ini tentu berbeda dengan pluralism yang harus mengabaikan imannya masing-masing, kebenaran dalam agama tidak dipersoalkan oleh para pemeluknya, dalam konsep ini tentu harus dipahami konsep umum kebenaran agama-agama. ${ }^{27}$ Pluralis tidak sama dengan sinkretisme yang memadukan unsur-unsur tertentu dari beberapa agama untuk dianut. ${ }^{28} \mathrm{Jadi}$, kebersamaan yang pluralis adalah kebersamaan yang dilakukan bersama-sama umat beragama, tanpa harus mengorbankan kenyakinan agama yang dianut.

Gereja harus membuka diri dengam lingkungan sosial dan membangun sikap toleransi dalam masyarakat, memberikan damai dan menjaga kerukuanan. Dalam situasi pandemik ini diperlukan kebersamaan untuk saling mendukung satu sama lain, membuang sikap egois dan fanatisme agama yeng berlebihan yang dapat berdampak kepada perpecahan. Dengan adanya sikap toleransi, warga suatu komunitas dapat hidup berdampingan secara damai, rukun, dan bekerja sama dalam mengatasi berbagai permasalahan yang terjadi dilingkungannya. ${ }^{29}$

\section{Meningkatkan Pelayanan Sosial}

Pendemi Covid-19 sangat berdampak kepada perekonomian seluruh lapisan masyarakat. Permasalahan sosial yang terjadi dalam lingkungan masyarakat menjadi tanggung jawab kita bersama. Gereja harus peduli dengan permasalahan sosial yang terjadi disekitarnya dan tidak boleh tertutup dan hanya mengurusi kehidupan seputar Kekristenan saja. Kegiatan pelayanan sosial dilakukan harus tanpa membedakan agama, suku, dan bahasa. Beberapa bentuk pelayanan sosial gereja di masa pendemi Covid-19 yang dapat dilakukan oleh gereja. Misalnya, melakukan bakti sosial pembagian sembako bagi masyara-

\footnotetext{
${ }^{26}$ Ginting and Ayaningrum, "Toleransi Dalam Masyarakat Plural."

${ }^{27}$ Fransiskus Irwan Widjaja and Noh Ibrahim Boiliu, Misi Dan Pluralitas Keyakinan Di Indonesia. (Yogyakarta: Penerbit Andi, 2019). 83

${ }^{28}$ Samuel Benyamin Hakh, Merangkai Kehidupan Bersama Yang Pluralis dan Rukun (Malang: BPK Gunung Mulia, 2017), 36

${ }^{29}$ Ginting and Ayaningrum, "Toleransi Dalam Masyarakat Plural."
} 
kat miskin dan terdampak pandemi Covid-19, membagikan makan nasi bungkus kepada para pemulung, tukang ojek, dan buruh lepas, melakukan pengobatan gratis bagi masyarakat, pembagian masker, dan ikut dalam gotong royong penyemprotan disinfektan dirumah dan lingkungan masyarakat.

Di tengah penyebaran Covid-19 yang terus meningkat dengan perkembangan varian baru yang semakin cepat dalam penyebarannya, peran gereja sangat dibutuhkan. Gereja tidak hanya memberitakan tentang hal-hal yang menyangkut kerohanian saja tetapi gereja juga harus berperan dalam mengajak masyarakat untuk peduli akan sesama dalam menjaga dan mematuhi protokol kesehatan, mengajak masyarakat untuk hidup bersih, dan sehat. Peran gereja dalam hal ini sangat sentral dalam melaksanakan tugas sosialnya ditengah pandemi Covid-19 saat ini.

\section{KESIMPULAN}

Kenyataan bahwa pandemi Covid-19 telah mengubah tatanan hidup dalam masyarakat Indonesia maupun dunia. Dalam situasi ini Kekristenan bukan hanya memperdebatkan perbedaan doktrin gereja dan pengajaran yang berbeda, melainkan umat Tuhan terpanggil untuk membuka diri dan terlibat dalam kemajemukan yang pluralis; membangun kebersamaan, membantu sesama manusia untuk meringankan beban dan penderitaan yang dialami oleh orang-orang yang terdampak pandemi virus Corona-19 tanpa melihat latar belakang suku, bangsa dan agama, sebagai bagian dari tugas yang diberikan oleh Tuhan Yesus untuk memperhatikan orang-orang yang ada dalam kesengsaraan. Kebersamaan yang pluralis tidak harus mengabaikan imannya masing-masing, kebenaran dalam agama tidak dipersoalkan oleh para pemeluknya dalam melakukan kegiatan kemanusiaan. Sikap toleransi dijunjung tinggi, toleransi tidak harus mengnyangkal iman yang eksklusif, melainkan dengan dasar iman yang eksklusif dapat menciptakan rasa toleransi. Menghargai dan mengasihi sesama yang berbeda agama bukan berarti menerima dan percaya kepada agama lain, namun dalam membangun sikap toleransi harus didasari prinsip kasih. Kekristenan harus hadir ditengah permasalahan sosial yang ada dan tetap melakukan nilai-nilai Kristiani dalam hidupnya sehari-hari, dan memberikan dampak yang baik ditengah pandemi Covid-19.

\section{REFERENSI}

Baharudin, Iksan, Chairul, and Muhammad Abdi, Nur. "Ancaman Krisis Ekonomi Global Dari Dampak Penyebaran Virus Corona (Covid-19).” AkMen Jurnal Ilmiah 17, no. 1 (2020): 710-718.

Brownlee, Malcolm. Tugas Manusia Dalam Dunia Milik Tuhan, Jakarta: BPK Gunung Mulia, 2004.

Daeli, Dorkas Orienti, and Sonny Eli Zaluchu. "Analisis Fenomenologi Deskriptif Terhadap Panggilan Iman Kristen Untuk Kerukunan Antar Umat Beragama Di Indonesia." SUNDERMANN: Jurnal Ilmiah Teologi, Pendidikan, Sains, Humaniora dan Kebudayaan 1, no. 1 (2019): 44-50.

DOKPEN KWI. Ajaran Sosial Gereja Tahun 1891-1991. Bogor: Grafika Mardi Yuana, 2011.

B. Kieser SJ. Solidaritas 100 Tahun Ajaran Sosial Gereja. Yogyakarta: PENERBIT KANISIUS, 1992.

Ginting, Rosalina, and Kiki Ayaningrum. “Toleransi Dalam Masyarakat Plural.” Jurnal Majalah Ilmiah Lontar (2009). 
Hakh, Samuel Benyamin. Merangkai Kehidupan Bersama Yang Pluralis dan Rukun, Malang: BPK Gunung Mulia, 2017

Hanoatubun, Silpa. "Dampak Covid-19 Terhadap Perekonomian Indonesia." Journal of Education, Psychology and Counseling 2, no. April (2020): 146-153.

https://bisnis.tempo.co/read/1332613/sri-mulyani-beberkan-8-dampak-covid-19sampai-hari-ini/full\&view=ok dikutip tanggal 17 Mei 2020

https://www.who.int/docs/default-source/coronaviruse/situation-reports/20200514covid-19-sitrep-115.pdf?sfvrsn=3fce8d3c_6 dikutip tanggal 25 maret 2020

https://primetimes.id/2020/04/07/peduli-covid-19-gbi-rawasari-sehati-berbagi-makansiang-gratis-untuk-ojol-opal-petugas-kebersihan-dan-tukang-parkir/ diakses tanggal 20 April 2020

Kraybill, Donald B. Kerajaan Yang Sungsang, Jakarta: BPK Gunung Mulia, 2012 Larosa, Arliyanus. Misi Sosial Gereja. Jakarta: Yayasan Kalam Kudus, 2001.

Lumintang, Stevri I. Teologi abu-abu, Malang: Gandum Mas, 2004

Nanuru, Ricardo F, and Lomas Beatris Limpong. "Lomas Beatris Limpong 2." Jurnal UNIERA 3, no. 1 (2014): 51-60.

Newbigin, Lesslie. Injil Dalam Masyarakat Majemuk, Jakarta: BPK Gunung Mulia, 1993

Poewadarminta, Kamus Besar Bahasa Indonesia, Jakarta: Balai Pustaka, 1980

Ricardo Freedom Nanuru. Gereja Sosial. Yogyakarta: CV Budi Utama, 2020.

Siahaya, Johannis, and Harls Evan R Siahaan. "Menggagas Hospitalitas Pentakostal:

Membaca Ulang Kisah Para Rasul 2: 44-47 Di Masa Pandemi." DUNAMIS: Jurnal Teologi dan Pendidikan Kristiani 5, no. 2 (2021): 426-439.

Soesilo, Yushak. "Pentakostalisme Dan Aksi Sosial: Analisis Struktural Kisah Para Rasul 2 : 41-47." DUNAMIS: Jurnal Teologi dan Pendidikan Kristiani 2, no. 2 (2018): 136-151. http://sttintheos.ac.id/ejournal/index.php/dunamis/article/view/172/134.

Widjaja, Fransiskus Irwan, and Noh Ibrahim Boiliu. Misi Dan Pluralitas Keyakinan Di Indonesia. Yogyakarta: Penerbit Andi, 2019.

Wijaya, Hengki, dkk. Strategi menulis Jurnal untuk ilmu Teologi, Semarang: Golden Gate Publishing, 2020

World Health Organization, https://www.who.int/dg/speeches/detail/who-directorgeneral-s-opening-remarks-at-the-media-briefing-on-covid-19---11-march-2020 dikutip tanggal 25 maret 2020

Yuli Yanti. "Misi Pelayanan Sosial Di Masa Pandemi Bagi Pembinaan Warga Gereja Jemaat Baru." https://osf.io/sq9h5 (n.d.).

Zaluchu, Sonny Eli. "Strategi Penelitian Kualitatif Dan Kuantitatif Di Dalam Penelitian Agama." Evangelikal 4, no. 1 (2020): 28-38. 